\title{
The discovery, biodiversity and conservation of Mabu forest-the largest medium-altitude rainforest in southern Africa
}

\author{
Julian Bayliss, Jonathan Timberlake, William Branch, Carl Bruessow \\ Steve Collins, Colin Congdon, Michael Curran, Camila de Sousa \\ Robert Dowsett, Francoise Dowsett-Lemaire, Lincoln Fishool \\ Timothy Harris, Eric Herrmann, Stephen Georgiadis, Mirjam Kopp \\ Bruce Liggiti, Ara Monadjem, Hassam Patel, Daniel Ribeiro \\ Chaire Spottishoode, Peter Taylor, Simon Willcock and Paul Smith
}

\begin{abstract}
The montane inselbergs of northern Mozambique have been comparatively little-studied, yet recent surveys have shown they have a rich biodiversity with numerous endemic species. Here we present the main findings from a series of scientific expeditions to one of these inselbergs,
\end{abstract}

Julian Bayliss' ${ }^{*} \ddagger$ (Corresponding author), CARL BRUessow and Hassam Patel Mulanje Mountain Conservation Trust, P.O. Box 139, Mulanje, Malawi. E-mail jlbayliss@yahoo.co.uk

Jonathan Timberlake, Timothy Harris and Paul Smith Royal Botanic Gardens, Kew, Richmond, UK

William Branch Department of Zoology, Nelson Mandela Metropolitan University, Port Elizabeth, South Africa

Steve Collins and Colin Congdon African Butterfly Research Institute, Nairobi, Kenya

Michael Curran and Mirjam Kopp Department of Environmental Sciences, Institute of Biogeography, University of Basel, Basel, Switzerland

CAMILA DE SousA Instituto de Investigacao Agraria de Mozambique, Ministerio de Agricultura, Maputo, Mozambique

Robert Dowsett and Francoise Dowsett-Lemaire Sumene, France

Lincoln Fishrool and ARA MONADJem $\S^{* *}$ BirdLife International, Cambridge, UK

Eric Herrmann c/o Percy FitzPatrick Institute, University of Cape Town, Cape Town, South Africa

Stephen Georgiadis and Bruce Liggitt Fauna \& Flora International, Cambridge, UK

Daniel Ribeiro Justiçia Ambiental, Maputo, Mozambique

Claire Spottiswoode Department of Zoology, University of Cambridge, Cambridge, UK

Peter TAYLoR Department of Ecology and Resource Management, School of Environmental Sciences, University of Venda, Thohoyandou, South Africa

SimON WiLLCOCK †† University of Leeds, Leeds, UK

${ }^{*}$ Also at: African Butterfly Research Institute, Nairobi, Kenya $\dagger$ Also at: Fauna \& Flora International, Cambridge, UK

¥Also at: Department of Zoology, University of Cambridge, Cambridge, UK

§Also at: All Out Africa Research Unit, Department of Biological Sciences,

University of Swaziland, Kwaluseni, Swaziland

Also at: Durban Natural Science Museum, Durban, South Africa

${ }_{* *}$ Also at: University of Southampton, Southampton, UK

$\dagger \dagger$ Also at: Department of Zoology and Entomology, Mammal Research Institute, University of Pretoria, Pretoria, South Africa

Received 10 December 2012. Revision requested 11 February 2013. Accepted 12 April 2013. First published online 11 February 2014.
Mt Mabu, and discuss the conservation implications. Comprehensive species lists of plants, birds, mammals and butterflies are presented. The most significant result was the discovery of a c. 7,880 ha block of undisturbed rainforest, most of it at medium altitude (900-1,400 m), a forest type that is not well represented elsewhere. It is possibly the largest continuous block of this forest type in southern Africa. To date, 10 new species (plants, mammals, reptiles and butterflies) have been confirmed from Mt Mabu, even though sampling effort for most taxonomic groups has been low. The species assemblages indicate a relatively long period of isolation and many species found are at the southern limit of their range. Conservationists are now faced with the challenge of how best to protect Mt Mabu and similar mountains in northern Mozambique, and various ways that this could be done are discussed.

Keywords Butterfly Forest, Google Forest, inselberg, Mabu, Mozambique, rainforest

This paper contains supplementary material that can be found online at http://journals.cambridge.org

\section{Introduction}

cross large parts of northern Mozambique (the region Anorth of the Zambezi River) the landscape is dominated by scattered granitic inselbergs, many of which rise above $1,500 \mathrm{~m}$ and support moist evergreen forest or rainforest on their slopes. These inselbergs form a poorlyknown archipelago of isolated rock and forest islands, usually surrounded by woodland. However, with the exception of the Namuli massif (Timberlake et al., 2009), these massifs and mountains have attracted comparatively little biological attention (Branch, 2011).

In contrast, similar mountains in southern Malawi, many $<200 \mathrm{~km}$ away, have been better studied, particularly the large massif of Mt Mulanje, which covers an area of c. $650 \mathrm{~km}^{2}$ and rises to $>3,000 \mathrm{~m}$, the second highest mountain range in southern Africa (Chapman, 1995; 
Strugnell, 2002; Bayliss et al., 2007). Conservation of the forests and biodiversity on Mt Mulanje was bolstered by the creation of a trust fund under the Mulanje Mountain Conservation Trust, an NGO that has now gained significant experience in the implementation of conservation action and in public engagement (Wisborg \& Jumbe, 2010).

Given the experience and knowledge of Mulanje Mountain Conservation Trust and others on Mt Mulanje, and the lack of such knowledge and conservation action on similar massifs in adjacent parts of northern Mozambique, a project was developed to explore the Mozambique mountains (Fig. 1) and to enhance their conservation by linking experience and knowledge in Malawi and Mozambique. This project, Monitoring and Managing Biodiversity Loss in South-east Africa's Montane Ecosystems, was a collaborative venture between the Royal Botanic Gardens, Kew and BirdLife International in the UK, the Instituto de Investigação Agrária de Moçambique and the Natural History Museum in Mozambique, and Mulanje Mountain Conservation Trust and the Forest Research Institute in Malawi. It was funded under the UK Government's Darwin Initiative from 2006 to 2009 (Smith \& Bayliss, 2009). Here we outline the main findings on Mt Mabu, especially for the forest areas, and provide species lists of plants, birds, mammals, reptiles, amphibians and butterflies. We also outline the main threats to this ecosystem and discuss how the conservation of Mabu and similar mountains in northern Mozambique, which form what is effectively an archipelago of islands, could be achieved.

\section{Discovery of Mt Mabu}

During the establishment phase of the Darwin project, satellite imagery from Google Earth (2013) was used in the selection of massifs or inselbergs in northern Mozambique that are higher than $1,500 \mathrm{~m}$ but relatively close to Mt Mulanje. The sites selected were Mts Chiperone, Namuli, Cucutea, Inago and Mabu in Mozambique, and Mchese Mountain adjacent to Mulanje in southern Malawi (Fig. 1). As Mt Mabu was identified (by JB) using Google Earth, it has sometimes been referred to as the Google Forest. It has more recently been called the Butterfly Forest because of the butterfly hill-topping phenomena that occurs on the summit at certain times of the year (Bright, 2012).

Once selected, reconnaissance visits were organized to each site to assess ecological status and accessibility. The first visit to Mt Mabu was in December 2005 by JB, CS, E. Hermann and HP. The approach began from the abandoned Cha Madal Tea Estate on the south-eastern slopes. During this reconnaissance an expanse of rainforest was seen beyond the peak extending to the horizon. Several days were spent exploring and recording forest biodiversity, especially birds, butterflies and plants (Spottiswoode et al.,
2008), and the forest was noted to be in excellent condition. Satellite imagery of the area was later used to determine forest extent in greater detail, suggesting that it may be the largest continuous tract of mid-altitude (900-1,400 m) rainforest (White, 1983) remaining in southern Africa.

\section{Findings}

\section{Forest extent}

As a result of the initial visits to Mabu, an unsupervised classification of forest extent was produced using a Landsat 7 ETM+ image (reference S-37-15-2000, $30 \mathrm{~m}$ resolution) from 2000, viewed through very near infra-red filters (Spottiswoode et al., 2008). This suggested a possible total forest extent of 5,000-7,000 ha, excluding the adjacent abandoned tea plantations. In October 2008 a more accurate draft land-cover map was created based on an unsupervised classification (maximum likelihood algorithm applied to a 6-band stack image) of a Landsat ETM+ image with $30 \mathrm{~m}$ resolution from July 2005. In the field this map was checked for accuracy of the classified vegetation types and a final vegetation map developed using the same Landsat image with radiometric and geometric correction. The following broad land-cover types were identified: moist forest, woodland, agricultural land, rock and bare ground. Based on this initial interpretation it was calculated that there are 6,937.4 ha of moist forest in planimetric view, largely above 1,000 $\mathrm{m}$ (Fig. 2), although this figure is an underestimate as much of the forest is on steep slopes. Assuming that the forest between 1,000 and $1,400 \mathrm{~m}$ is on a $30^{\circ}$ slope, and areas below $1,000 \mathrm{~m}$ and above $1,400 \mathrm{~m}$ are on a $15^{\circ}$ slope, slope correction factors (simple tangent values) were applied (Timberlake et al., 2012), giving a total estimated forest extent of 7,880 ha (Table 1).

\section{Forest carbon storage}

There is significant forest carbon stored in the forests on Mt Mabu. Carbon conversion values for particular forest types were used following those developed by Willcock et al. (2012) for the Eastern Arc Mountains in Tanzania. These values are more accurate than those available through the IPPC Tier 1 look-up values (GOFC-GOLD, 2008) for forest type and have $95 \%$ confidence intervals. The total aboveground live carbon value of the moist forest area is estimated to be $2,053,767 \mathrm{Mg}(2.05 \mathrm{Tg})$. The total carbon storage value including above-ground live vegetation, litter layer, coarse woody debris, below-ground live matter, and soil carbon is estimated to be c. $3,634,539 \mathrm{Mg}$ (3.6 Tg) for the rainforest area only. Following the carbon storage values presented in Willcock et al. (2012), if the total forest area was converted to bushland with scattered crops $\left(117.8 \mathrm{Mg} \mathrm{ha}^{-1}\right.$ ) a value of $0.9 \mathrm{Tg}$ of carbon would be lost, a loss of $2.7 \mathrm{Tg}$ of carbon 

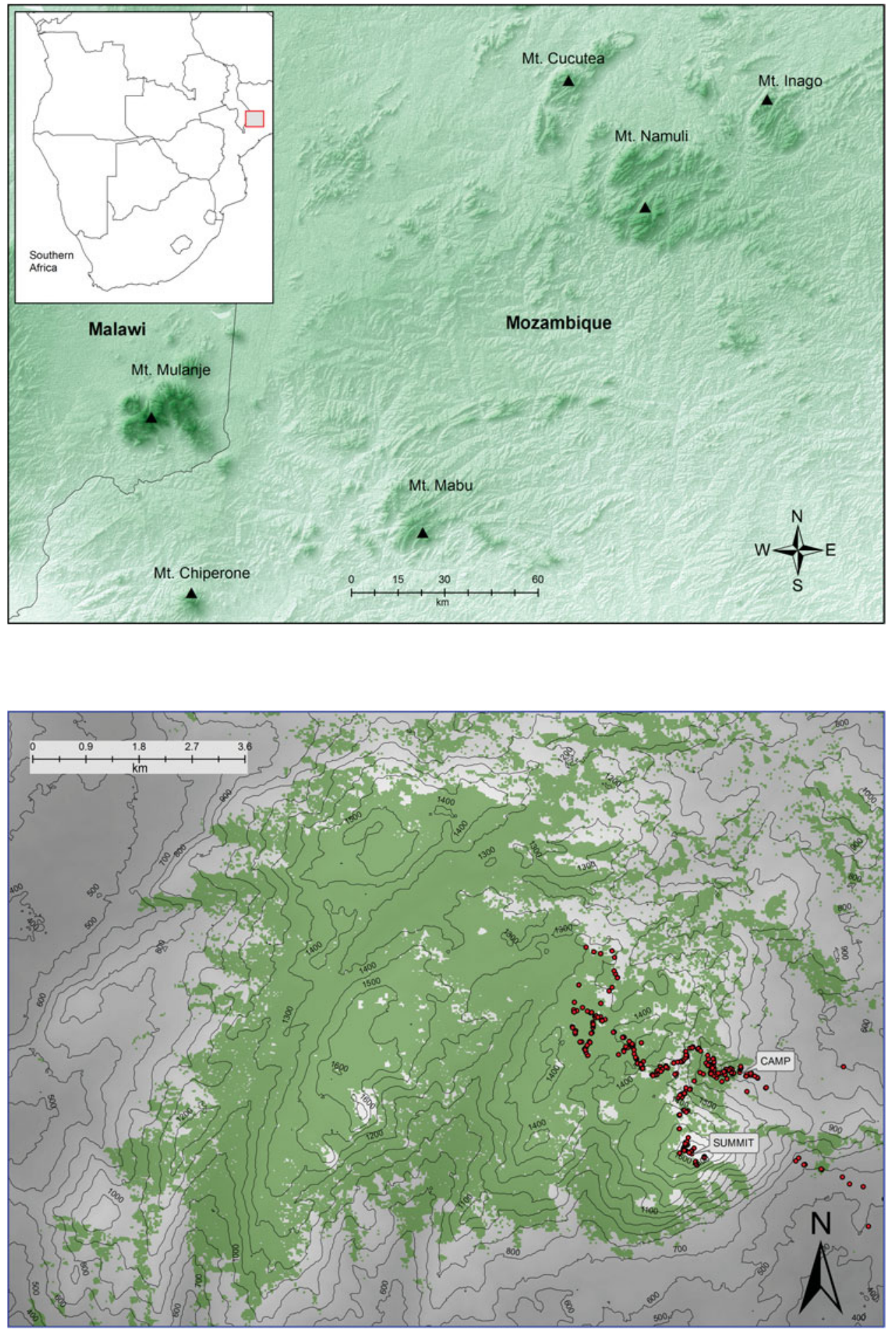

FIG. 1 The inselbergs that rise above $1,500 \mathrm{~m}$ in southern Malawi and north-east Mozambique.
FIG. 2 An overview of the forest extent (green) and the topography of the surrounding land. The red points (obtained with a global positioning system) indicate the extent of the forest explored. into the atmosphere. Likewise if the area was converted to woodland with scattered crops $\left(183.3 \mathrm{Mg} \mathrm{ha}^{-1}\right)$ the value would be $1.4 \mathrm{Tg}$, a loss of $2.2 \mathrm{Tg}$ of carbon.

\section{Biodiversity}

To date c. $20 \%$ of the forest has been at least partially surveyed biologically (Fig. 2), and it is envisaged that a significantly greater number of species will be found with further investigation. The majority of the biological study centred on the vicinity of the original survey camp (Fig. 2), an area that incorporates the main Mt Mabu summit and the immediate surrounding forest. A description of the main vegetation types and the various animal species found is given below. Checklists are provided in Supplementary Tables S1-S5 and Timberlake et al. (2012). 
TABLE 1 The area of forest cover (ha) by altitudinal class, with percentage of total forest cover, area corrected for slope (see text for details), associated above ground live carbon storage, and total carbon storage (above ground live carbon, litter, coarse woody debris, below ground live carbon and soil carbon; Willcock et al., 2012).

\begin{tabular}{llllll}
\hline & $\begin{array}{l}\text { Planimetric } \\
\text { forest area (ha) }\end{array}$ & $\%$ & $\begin{array}{l}\text { Forest area with } \\
\text { slope correction }\end{array}$ & $\begin{array}{l}\text { Above ground live carbon } \\
\text { storage }\left(\mathrm{Mg} \mathrm{ha}^{-1}\right)\end{array}$ & $\begin{array}{l}\text { Total forest carbon } \\
\left.\text { storage }(\mathrm{Mg} \mathrm{ha})^{-1}\right)\end{array}$ \\
\hline$<1,000 \mathrm{~m}$ (lowland forest) & $1,454.28$ & 21.0 & 1,600 & $1,600 \times 206.7=330,720$ & $1,600 \times 386.5=618,400$ \\
$\begin{array}{l}1,000-1,400 \mathrm{~m} \\
\text { (sub-montane forest) }\end{array}$ & $5,210.5$ & 65.8 & 5,270 & $5,270 \times 283.2=1,492,464$ & $5,270 \times 490.2=2,583,354$ \\
$>1,400 \mathrm{~m}$ (montane forest) & 919.50 & 13.2 & 1,010 & $1,010 \times 228.3=230,583$ & $1,010 \times 428.5=432,785$ \\
Total forest cover (ha) & $7,584.28$ & 100 & 7,880 & $2,053,767$ & $3,634,539$ \\
\hline
\end{tabular}

\section{Vegetation and Plants (Supplementary Table S1)}

Above $1,000 \mathrm{~m}$ altitude the majority of Mt Mabu is covered in rainforest; below this is woodland characterized by Pterocarpus angolensis and Syzygium cordatum, with overgrown tea Camellia sinensis plantations on the southeastern side (Timberlake et al., 2012). On the drier western and northern slopes, which were not visited, forest only appears to start at $1,400 \mathrm{~m}$, extending down to $1,200 \mathrm{~m}$ along drainage lines and in gullies. The rainforest is of two broad types (Dowsett-Lemaire \& Dowsett, 2009): medium-altitude rainforest at 950-1,400 $\mathrm{m}$ (c. 5,270 ha) and moister Afromontane rainforest at 1,350-1,400 $\mathrm{m}$ up to 1,650 m (c. 1,010 ha). Medium-altitude forest is characterized by $40-50 \mathrm{~m}$ tall trees of Strombosia scheffleri, Newtonia buchananii, Chrysophyllum gorungosanum and Maranthes goetzeniana, with occasional scattered figs (Ficus spp.). Subcanopy trees include Drypetes gerrardii, Funtumia africana, Garcinia kingaensis, Diospyros abyssinica and Rawsonia lucida and a number of Rubiaceae such as Heinsenia diervilleoides and Tricalysia pallens. The main canopy liana is Millettia lasiantha. Large clumps of the bamboo Oreobambos buchwaldii are found on drier slopes and in gullies. In Afromontane forest the canopy is lower at 20-25 m, down to $10-15 \mathrm{~m}$ at its upper limit. Typical tree species at lower altitudes include Olea capensis and Podocarpus latifolius, with Tabernaemontana stapfiana, Garcinia kingaensis, Myrianthus holstii and Synsepalum muelleri in the sub-canopy, and Rapanea melanophloeos, Aphloia theiformis, Faurea racemosa, Macaranga capensis, Prunus africana and Syzygium guineense afromontanum become more common at higher altitdues.

Above the forest, at 1,600-1,700 $\mathrm{m}$, rounded granite peaks support scattered patches of montane shrubland surrounded by clumps of the sedge Coleochloa setifera and the grass Danthoniopsis sp. This shrubland comprises stunted trees of Rapanea melanophloeos along with Syzygium cordatum, Aphloia theiformis, Maytenus acuminata and the shrubs Aeollanthus buchnerianus and Tetradenia riparia. In more exposed areas the dominant low shrub is Aeschynomene nodulosa along with Kotschya recurvifolia.
Some plant species of particular conservation interest were found, and two new species (the mistletoe Helixanthera schizocalyx and a shrub Vepris sp. nov.). However, some species previously thought to be endemic to other mountains, such as the orchid Polystachya songaniensis, previously known only from Mts Mulanje and Zomba in Malawi, and the bulbous herb Dianella ensifolia previously known only from the Chimanimani Mountains, were also found.

\section{Birds (Supplementary Table S2)}

A total of 126 bird species, including 18 Afromontane endemic or near-endemic species, have been recorded from Mabu (Spottiswoode et al., 2008; Dowsett-Lemaire, 2010). Some of these occur only above 1,350-1,400 m; e.g. Rameron pigeon Columba arquatrix, bar-tailed trogon Apaloderma vittatum, starred robin Pogonocichla stellata, Swynnerton's robin Swynnertonia swynnertoni, Namuli apalis Apalis (thoracica) lynesi, dapple-throat Modulatrix orostruthus and Cape batis Batis capensis dimorpha. The list includes seven species on the IUCN Red List (IUCN, 2013): southern banded snake eagle Circaetus fasciolatus (Near Threatened) occurs in small numbers and mainly below 1,00o m; spotted ground thrush Zoothera guttata (Endangered, Mabu and Namuli being the only likely breeding locations in Mozambique) is apparently rare; Cholo alethe Alethe choloensis (Endangered) is common, especially above $1,200 \mathrm{~m}$, and Mulanje is one of the two most important areas for the conservation of the species; Gunning's akalat Sheppardia gunningi (Near Threatened), with an important population at $400-1,350 \mathrm{~m}$, although it occurs in the tea forest; Swynnerton's robin (Vulnerable) occurs commonly above $1,350 \mathrm{~m}$, and this population partly bridges the gap in its recorded distribution between those of eastern Zimbabwe/southern Mozambique and central Tanzania; Namuli apalis (Near Threatened) hitherto thought to be endemic to Namuli (where it is common) is rare and found only above $1,400 \mathrm{~m}$ but this discovery suggests the species may also be present on adjacent mountains; dapple-throat (Vulnerable), for which Mabu represents a small range 
extension to the south-west (from Namuli), is rare and found only above $1,400 \mathrm{~m}$. Thus Mabu's extensive forest cover is an important refuge for several rare and threatened bird species in this part of Africa.

\section{Mammals (Supplementary Table S3)}

Small mammals were opportunistically surveyed over several visits; 19 species were collected over 1,000-1,300 m comprising four species of rodents, three shrews and 12 species of bat. The four rodent species are tropical forest specialists and, except for Grammomys dolichurus, represent their southernmost known populations. The main rodent collected was the soft-furred mouse Praomys delectorum. Although the lesser pouched rat Beamys major has been included in the widespread Beamys hindei, and Lophuromys aquilus in the widespread Lophuromys flavopunctatus, leading to IUCN Red List categories of Least Concern, it is likely that these southern populations will prove to be distinct (Musser \& Carleton, 2005). Shrew species on Mt Mabu (Crocidura luna and Crocidura olivieri) are also associated with tropical forest and woodlands.

The bat assemblage is similar to that found on nearby mountains such as Mt Mulanje and is dominated by species of Rhinolophidae and Hipposideridae. A single specimen of an unidentified Kerivoula was collected; it seems to be distinct from the two recognized Southern African species, $K$. argentata and K. lanosa. One new species of horseshoe bat, Rhinolophus mabuensis (Taylor et al., 2012), was collected and was also found on neighbouring Mt Inago (Bayliss et al., 2010; Monadjem et al., 2010a).

Information on larger mammals was also recorded opportunistically and with the knowledge of a local hunter (Dowsett-Lemaire \& Dowsett, 2009). The blue monkey Cercopithecus albogularis is common within the forest and is hunted by the local community using bow and arrows, and Grant's bush baby Galagoides (zanzibaricus) granti was heard calling at night. Forest antelopes such as blue duiker Cephalophus monticola, bushbuck Tragelaphus scriptus and klipspringer Oreotragus oreotragus are hunted for bushmeat, primarily using gin-traps, along with the two hyrax species Procavia capensis and Heterohyrax brucei. According to local hunters leopard Panthera pardus are occasionally encountered. Buffalo Syncerus caffer and elephant Loxodonta africana were historically common in the forest although they have not been seen in recent years.

\section{Reptiles and Amphibians (Supplementary Table S4)}

Collections of herpetofauna recorded seven amphibian and 15 reptile species (nine lizards and six snakes), although most collecting has not been at optimum times.
Three new reptiles have been discovered including a forest viper Atheris mabuensis (Branch \& Bayliss, 2009), the southernmost record of the genus; a chameleon, Nadzikambia baylissi, belonging to a genus previously thought to be endemic to Mt Mulanje (Branch \& Tolley, 2010; Branch, 2011), and a new species of pygmy chameleon (Rhampholeon sp. nov) that awaits description (W.R. Branch et al., unpubl. data). Probable new species include an unusual large-scaled bush snake (Philothamnus cf. carinatus), and a tree snake (Dipsadoboa sp.). The taxonomic status of other species is also currently under investigation, including the status of a rare burrowing skink (Melanoseps sp.) and two cryptic leaf-litter frogs (Arthroleptis sp.). Many of the species recorded are at the southernmost limits of their ranges and have affinities to groups from the north and west.

\section{Butterflies (Supplementary Table S5)}

Butterflies on Mt Mabu have been studied in eight visits, and in various seasons (Congdon \& Bampton, 2009; Congdon et al., 2010; Timberlake et al., 2012), with a total of 203 taxa recorded. The expected total is likely to be c. 250 species, similar to the butterfly fauna of neighbouring mountains such as Mt Mulanje. The phenomenon known as hilltopping (Shields, 1967) was observed on Mt Mabu; hundreds of butterflies of many families gather en masse throughout October and November during 10.30-11.30 on the summit (Bright, 2012).

Four of these are new species (Baliochila sp. nov; Cymothoe sp. nov, R. Van Velsen et al., unpubl. data; Epamera sp. nov., J. Bayliss et al., unpubl. data; Leptomyrina (Gonatomyrina) sp. nov.), and there are three new subspecies (Papilio pelodurus ssp. nov; Baliochila woodi spp. nov; Neocoenyra bioculata ssp. nov), and 35 new records for Mozambique (Congdon et al., 2010). Several of the new species have also been caught on neighbouring mountains, such as the new Cymothoe (Mt Namuli, Mt Inago), the Epamera (first caught on Mt Namuli) and Leptomyrina (Mt Namuli, Mt Inago).

\section{Biogeographical considerations}

The high number of endemic species discovered on Mt Mabu and surrounding mountains suggests a long period of isolation and ancient linkages with the north. Within most taxonomic groups there is evidence of a significant influence from mountains to the north (Tanzania) and to the west (Malawi), such as the Eastern Arc Mountains and Moreau's Tanganyika-Nyasa Montane Chain, with the greater influence from the latter. This is particularly evident in the butterfly fauna (Congdon et al., 2010; R. Van Velsen et al., unpubl. data ). Many species and 
genera collected are at the southernmost limits of their range, such as the long-tailed pouched rat, the new bush viper, the new pygmy chameleon (Rhampholeon sp. nov.), burrowing skink (Melanoseps sp.), and the new montane Cymothoe butterfly.

The terrestrial small mammal fauna of these isolated relic montane forests of northern Mozambique forms an important southern refuge biogeographically, linked with the montane forests of central Malawi and eastern Africa (Kenya, Uganda, Tanzania, Democratic Republic of Congo), and that are not listed in the southern African subregion as defined by Skinner \& Chimimba (2005); i.e. occurring south of the Zambezi River.

Within the herpetofauna a number of species are shared with adjacent Mt Mulanje. Closely-related chameleons occur on both mountains, with Nadzikambia mlanjensis and Rhampholeon platyceps on Mt Mulanje and the sister taxa N. baylissi and Rhampholeon sp. nov on Mt Mabu (Branch \& Tolley, 2010). No forest viper (Atheris sp.) has been recorded from Mt Mulanje but A. mabuensis is now known from both Mt Mabu and Mt Namuli (Branch \& Bayliss, 2009).

Afromontane birds found on Mabu currently total 18 species, which is relatively low in comparison with neighbouring mountains (Mt Mulanje has 31). This is probably because of the limited extent of montane grassland and shrubland on Mabu, hence species such as the blue swallow Hirundo atrocaerulea cannot occur, and the areas covered by Afromontane forest (as opposed to mid altitude forest) are relatively small.

Rainforests generally contain few endemic plants in this part of Africa, most species being very local in occurrence but distributed in forests over a large part of the region. Some records show that Mabu's montane flora has similarities to that on Mt Mulanje (the orchid P. songaniensis), but some are of species previously only recorded from the Chimanimani and other mountains along the Mozambique/Zimbabwe border (the herbs Cryptostephanus vansonii and D. ensifolia), whereas others show links to mountains in southern Tanzania and northern Malawi (the herbs Crotonogynopsis usambarica, Mimulopsis arborescens and the parasite Viscum cylindricum).

As the number of endemic species discovered in northern Mozambique increases, so does the case for the recognition of a new montane ecoregion. The evidence outlined here suggests that this region is biogeographically distinct from the species assemblages on neighbouring mountain ranges such as the Eastern Arc Mountains in southern Tanzania (Burgess et al., 2006, 2007).

\section{Discussion}

The greatest threat to forest biodiversity on Mt Mabu is from encroachment of slash and burn agriculture around the edges of the forest block, especially from the north-east to south-east, and from bushmeat hunting using gin-traps. The present level of hunting is thought to be so high that populations of some species such as the crested guineafowl Guttera pucherani (Dowsett-Lemaire, 2010) could become locally extinct.

Although there are few trees of commercial interest, logging activities are increasing in the surrounding woodlands and neighbouring mountains, and the future of the surrounding Cha Madal tea estate will play a crucial role in the conservation of the forest as this will determine land use and employment opportunities in the immediate vicinity. The tea plantations are currently not commercially viable because of the type of tea grown (China hybrid) but there could be a future in the extraction of Camellia oil from the tea tree seeds. Because of its close proximity a link with the tea industry in Malawi could prove commercially viable.

Hitherto, because little was known about Mt Mabu and its forest beyond the local area, it was free from outside exploitation, despite Mozambique's booming economy. The recent scientific expeditions to Mt Mabu have given rise to extensive media coverage, and also to a desire (within Mozambique and in the wider community) to conserve such an important habitat. The diversity of endemic species raises the profile of the area, and more discoveries of new species are expected.

\section{Conservation recommendations}

A number of factors currently favour the conservation of the area: the local paramount chiefs, the provincial government, and the national government are all in favour of protection and conservation; the surrounding human population is currently low; the forest is in good condition; the discovery of new species has raised the conservation justification for its protection; and access to the area is poor, which has so far favoured its protection.

To address current and future threats there is a need for a strategic conservation management plan, supported by government and local communities. In 2009 the Government of Mozambique agreed to protect the forest but as yet it has not been gazetted as a protected area. However an initiative towards registering Mabu forest as an area for conservation and nature-based tourism use only, by the NGO Justiçia Ambiental, has started. The model for the conservation of Mt Mabu has not yet been determined but potential models include those of the Mulanje Mountain Conservation Trust in Malawi (Wisborg and Jumbe, 2010), the Amani Nature Reserve (2013) and Udzungwa Mountains National Park (2013), both in the Eastern Arc Mountains of Tanzania, and Gorongosa National Park in Mozambique (2013).

The communities around Mt Mabu have a vested interest in the ecosystem services that originate in the forest. Justiçia 
Ambiental and Fauna and Flora International, supported by the Critical Ecosystem Partnership Fund (CEPF, 2013), are working closely together to establish a communitybased organization to manage potential nature-based tourism activities. Although there are few large charismatic animals to attract this sort of tourism, Mt Mabu is particularly important for rare birds, and it supports a variety of endemic and restricted range species. Specialist bird or rainforest tours could have a limited potential for income generation, although probably insufficient to fund a conservation programme. Amani Nature Reserve and Udzungwa National Park already cater for specialist bird watching in northern Tanzania.

The development of low-impact tourism, managed in part by local communities, may be the most appropriate land use for the massif. This would require a programme for training and licensing local guides (educating the guides in local history, knowledge of the forest and its plants and animals, and an ability to communicate this for ecotourism) and a base accessible by road, ideally on the old Cha Madal tea estate on the south-east slopes of the mountain from which access to the mountain is easily gained.

Another reason for the protection of the forest on Mt Mabu is mitigation of climate change at a local level. Mabu's wet forest currently locks up a considerable quantity of carbon (3.6 Tg in total) that would be released if the forest is destroyed (Table 1). The forest area could also be entered under a carbon accreditation scheme. Bottled mineral water could be a commercially viable venture for Mabu (water from the largest rainforest in southern Africa).

\section{Research}

Despite a limited amount of field research, many new species have recently been discovered on Mt Mabu (Bayliss, 2008; Branch \& Bayliss, 2009; Timberlake et al., 2009, 2012; Branch \& Tolley, 2010; Congdon et al., 2010; Monadjem et al., 2010a; Harris et al., 2011; Taylor et al., 2012; J. Bayliss et al., unpubl. data ; W.R. Branch et al., unpubl. data ; R. Van Velsen et al., unpubl. data ) and neighbouring inselbergs (Bayliss et al., 2010; Fishpool \& Bayliss, 2010; Staude et al., 2011; Savel \& Bayliss, 2012). The forest is particularly important for rare bird species. Further research should focus on taxonomic groups that have not been surveyed in sufficient detail, such as primates, small mammals, herpetofauna and invertebrates. A more detailed plant survey would increase the number of new plant records, particularly once the northern and western sides of the mountain are explored. In addition, the factors determining forest extent require investigation.

More broadly, a comparative study is needed of the high altitude inselbergs $\left(>_{1,500} \mathrm{~m}\right)$ across northern Mozambique and southern Malawi, and those further afield in southern Tanzania and eastern Zimbabwe, focusing on the distribution ranges of endemic species. These mountain ranges are of similar age and our findings suggest that they share similar biological assemblages. On this basis it may be appropriate to consider the recognition of a new montane ecoregion based on the south-central African montane inselbergs, possibly following a similar delimitation approach used for the Eastern Arc Mountains (Platts et al., 2011).

The reason Mt Mabu remained unfamiliar to the outside world, and largely undisturbed, lay in its remoteness and inaccessibility. Now that Mozambique is receiving increasing foreign investment and subsequent development, Mabu's forest is under potential threat from commercial logging and clearance for local agriculture. Measures need to be taken to protect it from these and similar threats such as unsustainable levels of hunting and wildfires.

\section{Acknowledgements}

We thank the following people and organizations who have contributed significantly to the knowledge we have gained of Mabu (in alphabetical order): Susana Baena, Ivan Bampton, Aurélio Banze, Jeff Barbee, Werner Conradie, Michael Curran, Savel Daniels, Jonah Fisher, Jorge Francisco, Martin Hassan, Eric Hermann, Justin Maguire, Hermenegildo Matimele, Steven Mphamba, Jose Carlos Monteiro, Justin Moat, Lucas Sabão, Malaika Sacranie, Neil Shaw, Thomas Timberlake, Krystal Tolley, AC Van Bruggen, Antonia Windsor, the BBC Natural History Unit, and Sir David Attenborough.

\section{References}

Ackery, P.R., Smith, C.R. \& VAne-Wright, R.I. (1995) Carcasson's African Butterflies: An annotated Catalogue of the Papilionoidea and Hesperioidea of the Afrotropical Region. British Museum (Natural History), London, UK.

African Plant Database (2012) Conservatoire et Jardin botaniques de la Ville de Genève and South African National Biodiversity Institute, Pretoria. Version 3.4.o. Http://www.ville-ge.ch/musinfo/ $\mathrm{bd} / \mathrm{cjb} /$ africa/ [accessed 2012].

Amani Nature Reserve (2013) Http://www.amaninature.org [accessed 5 December 2013].

BAyliss, J. (2008) Danger and discoveries in northern Mozambique. Lepsoc News Africa, 4, 3-6.

Bayliss, J., Makungwa, S., Hecht, J., Nangoma, D. \&

BRUEssow, C. (2007) Saving the island in the sky: the plight of the Mount Mulanje cedar Widdringtonia. Oryx, 41, 64-69.

Bayliss, J., Monteiro, J., Fishpool, L., Congdon, C., Bampton, I., Bruessow, C. et al. (2010) Biodiversity and Conservation of Mount Inago, Mozambique. Report for Darwin Initiative Award 15/036. Royal Botanic Gardens, Kew, UK.

BRANCH, W.R. (1998) Field Guide to the Snakes and other Reptiles of Southern Africa. Struiks, Cape Town, South Africa.

Branch, W.R. (2011) Treasure Mountain. Africa Geographic, 19, 30-33. 
Branch, W.R. \& Bayliss, J. (2009) A new species of Atheris (Serpentes: Viperidae) from northern Mozambique. Zootaxa, 2113, 41-54.

Branch, W.R. \& Tolley, K.A. (2010) A new species of chameleon (Sauria: Chamaeleonidae: Nadzikambia) from Mount Mabu, central Mozambique. African Journal of Herpetology, 59, 157-172.

Bright, M. (2012) Africa: Eye to Eye with the Unknown (Foreword D. Attenborough), pp. 159-161. BBC Natural History Unit, Quercus Editions, London, UK.

Burgess, N.D., Butynski, T.M., Cordeiro, N.J., Doggart, N.H., FJelds̊̊, J., Howell, K.M. et al. (2007) The biological importance of the Eastern Arc Mountains of Tanzania and Kenya. Biological Conservation, 134, 209-231.

Burgess, N.D., Hales, J.D., Ricketts, T.H. \& Dinerstein, E. (2006) Factoring species, non-species values and threats into biodiversity prioritisation across the ecoregions of Africa and its islands. Biological Conservation, 127, 383-401.

Cabral, A. (2000) Borboletas de Moçambique. Natural History Museum, Maputo, Mozambique \& Lisbon, Portugal.

CEPF (2013) Ecosystem Profile-Eastern Afromontane Hotspot. Prepared by BirdLife International. Critical Ecosystem Partnership Fund, Washington, DC, USA.

Chapman, J.D. (1995) The Mulanje Cedar: Malawi's National Tree. The Society of Malawi, Blantyre, Malawi.

Congdon, C. \& Bampton, I. (2009) Musings from Mount Mabu. Metamorphosis, 20, 45-107.

Congdon, C., Collins, S. \& BAyliss, J. (2010) Butterflies of south east Africa's mountains (Mozambique and Malawi).

Metamorphosis, 21, 45-107.

D'Abrera, B.L. (1980) Butterflies of the Afrotropical Region. Lansdowne Editions, Melbourne, Australia.

Dowsett-Lemaire, F. (2010) Further ornithological exploration of Namuli and Mabu Mountains (northern Mozambique), and the urgent need to conserve their forests. African Bird Club Bulletin, 17 , 159-177.

Dowsett -Lemaire, F. \& Dowsett, R.J. (2006) The Birds of Malawi. Tauraco Press \& Aves, Liège, Belgium.

Dowsett-Lemaire, F. \& Dowsett, R.J. (2009) The Avifauna and the Forest Vegetation of Mabu Mountain, Northern Mozambique, with Notes on Mammals (October 2008). Dowsett-Lemaire miscellaneous Report 66. Http://www.kew.org/ ucm/groups/public/documents/document/kppcont_046100.pdf [accessed 5 December 2013].

Fishpool, L.D.C. \& BAYliss, J. (2010) Brief notes on the birds of Mount Inago, northern Mozambique. African Bird Club Bulletin, 17, 198-201.

Gorongosa National Park (2013) Http://www.gorongosa.org [accessed 5 December 2013].

GOFC-GOLD (2008) Reducing Greenhouse Gas Emissions from Deforestation and Degradation in Developing Countries: A Source book of Methods and Procedures for Monitoring, Measuring and Reporting. GOFC-GOLD Report version COP13-2. GOFC-GOLD Project, Alberta, Canada.

Google Earth (2013) Http://www.google.com/earth [accessed 5 December 2013].

Harris, T., Darbyshire, I. \& Polhill, R. (2011) New species and range extensions from Mt Namuli, Mt Mabu and Mt Chiperone in northern Mozambique. Kew Bulletin 66, 241-251.

IUCN (2013) IUCN Red List of Threatened Species v. 2013.2. Http:// www.iucnredlist.org [accessed 5 December 2013].

Kielland, J. (1990) Butterflies of Tanzania. Hill House, London, UK.

Libert, M. (1999) Révision des genres Epitola Westwood, Hypophytala Clench et Stempfferia Jackson, et description de trois nouveaux genres
(Lepidoptera Lycaenidae). A.B.R.I., Nairobi \& Lambillonea, Tervuren, Belgium.

Libert, M. (2004) Revision des Deudorix africains (Lepidoptera, Lycaenidae). A.B.R.I., Nairobi, Kenya \& Lambillionea, Tervuren, Belgium.

Monadjem, A., Schoeman, M.C., Reside, A., Pio, D.V., Stoffberg, S., Bayliss, J. et al. (2010a) A recent inventory of the bats of Mozambique with documentation of seven new species for the country. Acta Chiropterologica, 12, 371-391.

Monadjem, A., Taylor, P.J., Cotterill, F.P.D. \& Schoeman, M.C. (2010b) Bats of Southern and Central Africa: A Biogeographic and Taxonomic Synthesis. Wits University Press, Wits, South Africa.

Musser, G.G. \& Carleton, M.D. (2005) Superfamily Muroidea. In Mammal Species of the World, 3rd edition (eds D.E. Wilson \& D.M. Reeder), pp. 894-1531. The Johns Hopkins University Press, Baltimore, USA.

Platts, P.J., Burgess, N.D., Gereau, R.E., Lovett, J.C., Marshall, A.R., McClean, C.J. et al. (2011) Delimiting tropical mountain ecoregions for conservation. Environmental Conservation $38,312-324$.

Pringle, E.L.L., Henning, G.A. \& Ball, J.B.(eds) (1994) Penningtons Butterflies of Southern Africa, 2nd edition. Struik, Cape Town, South Africa.

SAVEL, D. \& BAYliss, J. (2012) Unexplored refugia of biodiversity: mountainous regions in Mozambique and Malawi yield two novel freshwater crab species (Potamonautidae: Potamonautes). Zoological Journal of the Linnean Society, 164, 498-509.

SHIELDS, O. (1967) Hilltopping: an ecological study of summit congregation behavior of butterflies on a southern California hill. The Journal of Research on the Lepidoptera, 6, 69-178.

Skinner, J.D. \& Chimim B A, C.T. (2005) The Mammals of the Southern African Subregion. Cambridge University Press, Cambridge, UK.

SMith, P. \& BAYliss, J. (2009) Darwin project discovers virgin rainforest in Mozambique. Darwin News, 14, 3.

Spottiswoode, C.N., Patel, I.H., Herrmann, E., Timberlake, J. \& BAyliss, J. (2008) Threatened bird species on two little-known mountains (Chiperone and Mabu) in northern Mozambique. Ostrich, 79, 1-7.

Staude, H., Bayliss, J. \& Sihvonen, P. (2011) The Mulanje Tiger Moth Prout, 1922, new status, a critically endangered species from Malawi (Lepidoptera: Geometridae: Diptychinae). Metamorphosis, 22, 49-64.

Strugnell, A.M. (2002) Endemics of Mount Mulanje-the endemic spermatophytes of Mount Mulanje, Malawi. Systematics and Geography of Plants, 72, 11-26.

Taylor, J., Stoffberg, S., Monadjem, A., Schoeman, M.C., Bayliss, J. \& Cotterill, F.P.D. (2012) Plio-Pleistocene speciation of five new species of African horseshoe bats (Rhinolophidae): morphological divergence of dwarfs and giants across an Afromontane Archipelago. PLoS ONE, 7, e41744.

Timberlake, J.R., Bayliss, J., Dowsett -Lemaire, F., Congdon, C., Dowsett, R., Francisco, J. et al. (2012) Mt Mabu, Mozambique: Biodiversity and Conservation. Report produced under the Darwin Initiative Award 15/036. Royal Botanic Gardens, Kew, UK. Http://www.kew.org/ucm/groups/public/documents/document/ kppcont_067897.pdf [accessed 5 December 2013].

Timberlake, J.R., Dowsett-Lemaire, F., Bayliss, J., Alves, T., Baena, S., Bento, C. et al. (2009) Mt Namuli, Mozambique: Biodiversity and Conservation. Report for Darwin Initiative Award 15/036. Royal Botanic Gardens, Kew, UK.

Udzungwa Mountains National Park (2013) Http://www. tanzaniaparks.com/uzdungwa.html [accessed 5 December 2013]. 
White, F. (1983) The Vegetation of Africa. Natural Resources Research No. 20. UNESCO, Paris, France.

Willcock, S., Phillips, O.L., Platts, P.J., Balmford, A., Burgess, N.D., Lovett, J.C., et al. (2012) Towards regional, error-bounded landscape carbon storage estimates for data-deficient areas of the world. PLOS ONE, 7, e44795.

Williams, M.C. (2012) Afrotropical Butterflies \& Skippers: A Digital Encyclopaedia, 11th edition. Http://www.atbutterflies.com [accessed 5 December 2013].

Wisborg, P. \& Jumbe, C.B.L. (2010) Mulanje Mountain Biodiversity Conservation Project: Mid-Term Review for the
Norwegian Government. Noragric Report No. 57. Department of International Environment and Development Studies, Noragric, Aas, Norway.

\section{Biographical sketches}

The authors comprise of a multidisciplinary team of conservation scientists, taxonomists, foresters, and development managers, members of civil societies and museums, and $\mathrm{PhD}$ students. Collectively the team has many years of experience working in Africa, and in particular Mozambique. 